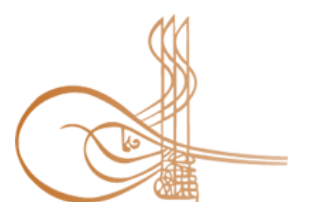

www.turkishstudies.net/religion

\section{Turkish Studies - Comparative Religious Studies}

eISSN: 2667-5544

Research Article / Araștırma Makalesi

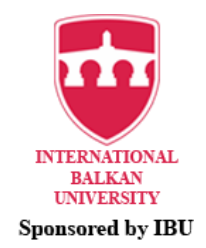

Sponsored by IBU

\title{
Hâkim en-Nîsâbûrî Tarafından Hadis Uydurmakla İtham Edilen Kadılar
}

\author{
Qadis Accused of Making up Hadiths by Hâkim en-Nîsâbûrî
}

\author{
Fikret Özçelik*
}

\begin{abstract}
In addition to the famous muhaddiths in the area of hadith narration, it is a fact that there are narrators known by different names. Some of these are qadis that are somehow associated with hadith narration. However, it is not possible to consider all qadis at the same level in the hadith narration. In this context, it cannot be said that those who are famous in fatwa and figh are also prominent in the hadith narration, but there are some exceptions. In addition, it is assumed that the hadith critics do not regard being a qadi as a favorable profession. The main reason for this is that professions such as being a qadi may damage the narrator's report over time. In this context, it is reported that the narrations of many narrators, who took the post of qadi, were abandoned and criticized. The narrators are generally evaluated in terms of justice and their reports. Therefore, it is known that the disaffirmations directed to the narrators are not at the same level. In this context, the heaviest criticism that can be directed to the narrators is related to the subjects about justice issues such as falsehood and making up hadiths. In this study, the qadis accused of making up hadiths by Hâkim en-Nîsâbûrî have been addressed. These qadis are listed as İbn 'Ulâse, Nûh b. Derrâc, Mansûr b. Abdülhamid and Ebû'l-Bahterî. Based on the evaluation of Hâkim en-Nîsâbûrî, the translations of the mentioned qadis have been addressed within the framework of the jarh and ta'dil (discrediting and accrediting) literature, and the opinions of the hadith critics about these qadis have been explained. Thus, the accuracy of the claim that qadis made up hadiths and reasons for this have been mentioned. On the other hand, it has been tried to determine whether there are narrations of the relevant qadis in the primary hadith resources. However, within the scope of these four qadis, it has been tried to determine the relationship between qadis and hadith narration and their contribution to the hadith narration, and it has been established that the relevant qadis were not very active in hadith narration.
\end{abstract}

Structured Abstract: In general terms, it is possible to associate qadis with hadith narration. However, it cannot be said that those who are famous in fatwa and fiqh are also prominent in the hadith narration, but there are some exceptions. In addition, it is seen that the hadith critics do not regard being a qadi as a favorable profession. The main reason for this is that professions such as being a qadi may damage the narrator's report over time. That is why some narrators' narrations were abandoned after they took the post of qadi and their hadiths were not accepted as evidence. Therefore, it is seen that the jurist and muhaddith identities of the qadis are not regarded as equally reliable.

It is seen that well-known qadis such as Şurayh, İbn Şübrüme ve Muhammed b. Ebî Leylâ narrated very few hadiths. Therefore, it can be said that the qadis who are famous in the field of fatwa and fiqh are less engaged in the area of hadith narration. However, it is a fact that there are some exceptions such as Şa'bî.

\footnotetext{
* Dr. Öğr. Üyesi, Mardin Artuklu Üniversitesi, İslami İlimler Fakültesi, Temel İslam Bilimleri Bölümü Assistant Professor, Mardin Artuklu University, Faculty of İslamic Sciences, Department of Basic Islamic Sciences ORCID 0000-0001-5015-6167

ozcelik.21@hotmail.com

Cite as/ Atıf: Özçelik, F. (2020). Hâkim en-Nîsâbûrî tarafından hadis uydurmakla itham edilen kadılar. Turkish Studies

- Religion, 15(3), 393-410. https://dx.doi.org/10.47091/TurkishStudies.43801

Received/Geliş: 27 May/Mayıs 2020

Accepted/Kabul: 20 September/Eylül 2020

Copyright (C) INTAC LTD, Turkey 
Because Şa 'bî is a person known with both fatwa and hadith narration. On the other hand, Abdurrahman b. Ebî Leylâ and Saîd b. Cübeyr are among the qadis who mostly come to the fore with the hadith narration.

In his book titled as "el-Medhal ila ma'rifeti’s-sahîh mine’s-sakîm ve tebyîn mâ eşkele min esmâi’rricâl fî's-sahîhayn", Hâkim en-Nisâbûrî accused the qadis named İbn 'Ulâse, Nûh b Derrâc, Mansûr b Abdülhamid and Ebû'l-Bahterî of making up hadis.

Süfyan es-Sevri criticized his friend İbn 'Ulâse, who was appointed as qadi by Mehdî, to accept this post. Furthermore, hadith critics made various comments on İbn 'Ulâse. For example, İbn Sa'd and Yahyâ b. Maîn accepted him as reliable. Ebû Zür'a used the term "salih" (suitable) and İbn Adî used the term "hasan(good) hadith" for him. On the other hand, İbn Hacer stated his opinions about İbn 'Ulâse as "he is loyal, he makes mistakes".

The heaviest criticism about İbn 'Ulâse was made by Hafiz Ebû'l-Feth Muhammed b. Hüseyin elEzdî Ebû'l-Feth el-Ezdî, İbn Hibbân and Hâkim en-Nîsâbûrî According to the aforementioned critics, it is not lawful to write the narrations of İbn 'Ulâse conveyed especially from Evzâî. Hatîb Bağdâdi said that Ebû'lFeth went far ahead about İbn 'Ulâse.

When the hadith literature is reviewed, it is seen that İbn 'Ulâse has not many narrations. As far as can be determined, the narrations of İbn 'Ulâse are not included in the Bukhari and Muslim Sahih. He has one narration in the Sunan by Ebû Dâvud; two narrations in the Sunan by İbn Mâce; two narrations in the Sunan by Nesâî and two narrations in the Musnad by Ahmed b. Hanbel. In addition to this, there are two fatwas of İbn 'Ulâse in the Musannaf by Abdürrezzâk es-San'ânî. There are also four narrations by him in the Musannaf by İbn Ebî Şeybe and all four narrations consists of maqtu' narrations. Dârekut pointed out the narrations that İbn 'Ulâse had made a mistake.

It can be said that the opinions of Hatîb and İbn Hacer regarding İbn 'Ulâse are more acceptable. In other words, it can be said that İbn Ulâse made mistakes in some of his narrations. However, these mistakes should be evaluated in the context of the weakness of İbn 'Ulâse's reports. In connection with this, the evaluations of some scholars such as Ebû'l-Feth el-Ezdî, İ̉nn Hibbân and Hâkim en-Nîsâbûrî as " İbn 'Ulâse is a liar, it is not halal to narrate from him." are actually harsh criticism and these opinions are open to dispute.

One of the narrators accused of making up hadiths by Hâkim en-Nisâbûrî is Nûh b. Derrâc. Nûh b. Derrâc, who learned fiqh from Ebû Hanîfe and İbn Şübrüme, was appointed as a qadi first to Kufa and then to the east of Baghdad.

As far as can be determined, Yahyâ b. Maîn was the first scholar to criticize Nûh b. Derrâc. İbn Maîn described Nûh b. Derrâc as a liar and degenerated person. After Yahyâ b. Maîn, the harshest disaffirmation about Nûh b. Derrâc was expressed by Ebû Dâvud and Nesâî. On the other hand, both scholars did not say the reason for their disaffirmations. İbn Hibbân and Hâkim en-Nîsâbûrî also stated that Nûh b. Derrâc had made up hadiths from reliable narrators.

Hadith critics such as Buhârî, İclî, Ebû Hâtim er-Râzî, Ali b. Medînî criticized Nûh b. Derrâc with milder expressions. The criticism of these scholars is mostly directed towards his reports. Muhammed $b$. Abdullah b. Numeyr described Nûh b. Derrâc with the term of reliable and Ebû Zür'a suggested that taking hadiths from him was not considered as risky. Besides, İbn Adî accepted Nûh b. Derrâc as a narrator of whom hadiths were written. The approach of İbn Numeyr to the Kufa narrators was honored by Yahyâ b. Maîn ve Ahmed b. Hanbel. Since Nûh b. Derrâc was also from Kufa, it is important that İbn Numeyr accepted him as reliable.

As far as can be determined, Kutub al-Sittah authors and muhaddits such as Ahmed b. Hanbel did not report hadiths from Nûh b. Derrâc. However, it is possible to find the narrations of Nûh b. Derrâc in the Musnad of Ebu Hanife. Although Hâkim en-Nîsâbûrî accused Nûh b. Derrâc of making up hadiths, he reported two narrations from him. In addition, it was determined that Nûh b. Derrâc opposed to reliable narrators in some of his narrations.

In this context, the accusation made by some scholars, especially İbn Maîn and Hâkim en-Nîsâbûrî, against him as being a liar and making up hadiths is thought to be open to discussion. Instead, the views of scholars such as Buhârî ve Ebû Hâtim are considered more reasonable. However, Nûh b. Derrâc narrated very few hadiths, so it is seen that he did not come to the fore as a hadith narrator. 
Mansûr b. Abdülhamid was one of those who was accused of making up hadith. The views of the hadith critics such as Yahyâ b. Maîn, Ahmed b. Hanbel, Buhârî and Ebû Hâtim regarding Mansûr b. Abdülhamid, who served as a qadi in Marw, were not found in the literature. İbn Ebî Hâtim only included his translation in his work, but he did not make any statements about the narrator's jarh and ta'dil (discrediting and accrediting). İbn Adî did not include the translation of Mansûr b. Abdülhamid.

One of the most important names among those who criticized Mansûr b. Abdülhamid is İbn Hibbân. According to İbn Hibbân, Mansûr b Abdülhamid made up hadiths and it is not halal to narrate from him. The same claim was expressed by İbn Asâkir and Hâkim en-Nîsâbûrî. As far as can be determined, the narration of Mansûr b. Abdülhamid was not included in the primary hadith resources. Therefore, it can be said that Mansûr b. Abdülhamid did not come into prominence as a hadith narrator. In this context, this must be the reason why the first term critics did not declare any opinion about him.

One of the qadis characterized by the hadith critics as making up hadiths was Vehb b. Vehb, known under the name of Ebû'l-Bahterî. He was appointed as a qadi by Hârûnürreşî̉ first to Baghdad and then to Madinah.

He was accused of being a liar and making up hadiths by the hadith critics such as Ebû'l-Bahterî; Yahyâ b. Maîn, Ahmed b. Hanbel, İshâk b. Râhûye, Buhârî Müslim and Ebû Hâtim. Likewise, Cûzcânî Ebû Zür'a, er-Râzî Nesâî Vekî', İbn Hibbân Dârekutnî, Hâkim en-Nîsâbûrî criticized him with the heaviest expressions of jarh. İbn Adî, Dârekutnî and İbnü'l-Cevzî pointed out a number of narrations made up by Ebû'lBahterî

Juynboll stated that especially Kufa and Medina qadis are generally known with their hadiths. It was seen that Kufa and Medina qadis discussed in this study were not among those who were known for their hadiths. In this context, it was determined that these four qadis were not very active in the area of hadith narration.

Keywords: Hadith, narration, qadi, İbn 'Ulâse, Nûh b. Derrâc, Mansûr b. Abdülhamid, Ebû'l-Bahterî.

Öz: Hadis rivayetinde yer alan meşhur hadisçilerin yanında, farklı kimliklerle bilinen râvilerin varlığı da bir hakikattir. Bunlardan bazıları da bir şekilde hadis rivayetiyle ilişkilendirilen kadılardır. Ancak hadis rivayetinde bütün kadıları aynı seviyede kabul etmek mümkün görünmemektedir. Bu bağlamda istisnalarla beraber fetva ve fikıhta meşhur olanların hadis rivayetinde de ön plana çıktığı söylenemez. Bunun yanı sıra hadis münekkitlerinin kadılık mesleğine olumlu bakmadıkları telakki edilmektedir. Bunun temel nedeni, kadılık gibi meşguliyetlerin zaman içerisinde râvinin zabtına zarar verme ihtimalidir. Bu bağlamda kadılık görevini üstlenen birçok ravinin rivayetlerinin terk edildiği ve tenkit edildikleri nakledilmektedir. Râviler genel olarak adalet ve zabt açısından değerlendirilmektedir. Dolayısıyla râvilere yapılan cerhlerin aynı seviyede olmadığı bilinmektedir. Bu bağlamda râvilere yöneltilebilecek en ağır tenkit, yalancılık ve hadis uydurmak gibi adalet vasıflarına dair olanlardır. Bu çalışmada Hâkim en-Nîsâbûrî tarafından hadis uydurmakla itham edilen kadılar ele alınmıștır. Bu kadılar İbn 'Ulâse, Nûh b. Derrâc, Mansûr b. Abdülhamid ve Ebû'l-Bahterî' dir. Hâkim en-Nîsâbûrî'nin değerlendirmesinden yola çıkılarak ismi geçen kadıların tercemeleri cerh-ta'dîl literatürü çerçevesinde ele alınmış ve hadis münekkitlerinin söz konusu kadılar hakkındaki kanaatleri izah edilmiştir. Böylelikle kadılara nispet edilen hadis uydurma iddiasının hakikatine ve sebeplerine değinilmiştir. Öte yandan temel hadis kaynaklarında söz konusu kadıların rivayetlerinin olup olmadığı tespit edilmeye çalışılmıştır. Bununla beraber bu dört kadı bağlamında kadıların hadis rivayeti ile ilişkileri ve hadis rivayetindeki katkıları tespit edilmeye çalışılmış ve söz konusu kadıların hadis rivayetinde çok aktif olmadığı görülmüştür.

Anahtar Kelimeler: Hadis, rivayet, kadı, İbn ‘Ulâse, Nûh b. Derrâc, Mansûr b. Abdülhamid, Ebû’l-Bahterî.

\section{Giriş}

Hadislerin günümüze kadar ulaşmasında büyük rol üstlenen râviler ricâl ilmi ilkeleri çerçevesinde ele alınmalıdır. Bundan dolayı hadis rivayetiyle bir şekilde ilişkili olanlar, hadis münekkitlerinin görüşleri ve kanaatleri bağlamında sika veya zayıf olarak telakki edilmiştir. Bunun 
yanı sıra hadis rivayetinde yer alan meşhur hadisçilerin yanında, farklı kimliklerle bilinen râvilerin varlığı da bir hakikattir. Bunlardan bazıları da bir şekilde hadis rivayetiyle ilişkilendirilen kadılardır.

İslam teşrî tarihinde kadıların konumu elbette ki önemlidir. Ancak kimi kadıların, ricâl edebiyatındaki tercemeleri bağlamında söylenen ifadelerin zihinlerde bazı sorunlara yol açtığı söylenebilir. Başka bir ifadeyle bazı kadılar hadis münekkitleri tarafından "kezzâb", "yalancı" ve "hadis uydurmak" gibi en ağır ifadelerle cerh edilmiştir. Bunun yanı sıra kadıların, tarihin seyri içerisinde hadis rivayetindeki katkıları (Endülüs örneğinde kadıların hadis ilmine katkıları için bk. (Öztoprak, 2013) ve hadisçilik kimlikleri gibi konular tartışma konusu olmuştur (Juynboll, 2002: 105-126). Söz gelimi Juynboll'un tespitine göre Misırlı kadıların ancak yüzde otuzu hadisle bir şekilde meşgul olmakla bilinmiştir. Aynı şekilde Suriye kadılarının yirmi üçünden sadece sekizinin hadis rivayet ettiği tespit edilmiştir. Ancak Medîneli kadılarla ilgili farklı bir tablo ortaya çıkmıştır. Durumları incelenen otuz beş kadıdan yirmi altısının hadis rivayet etmekle şöhret bulduğu görülmüştür. Mekkeli kadıların da hadisçi kimliklerinin ağır bastığı görülmüştür. Nitekim incelenen on dört kadıdan sekizi hadis iştigaliyle bilinmiştir.(Juynboll, 2002: 116). Basralı kadılardan da kırk altısından otuz ikisinin hadis rivayet ettiği söylenmiştir. İncelenen Kûfe kadılarının üçte ikisi de bir şeklide hadis rivayetiyle ilişkilendirilmiştir. Aynı şeklide Bağdatlı kadılardan da hadisle meşgul olanların sayısının fazla olduğu göze çarpmıştır (Juynboll, 2002: 110-122). Bununla beraber bazı istisnalar dışarıda tutulursa kadıların fikhî ve hadis rivayeti şöhretleri arasında ters orantı olduğu da söylenmiştir (Koç, 2019: 134). Bunun yanı sıra kadılarla ilgili yapılan bazı çalışmalarda da hadisçi kimliğiyle ön plana çıkan kadıların az olduğu görülmüştür (Geniş bilgi için bk. Koçinkağ, 2017: 133141).

Doğrudan hadis uydurmakla itham edilen kadılarla ilgili herhangi bir çalışma tarafımızdan tespit edilememiştir. Hal böyleyken ricâl edebiyatında özellikle haklarında kezzâb gibi cerhin en ağır ifadesi kullanılan ve hadis uydurmakla suçlanan kadıların durumlarının ele alınmasının, alana katkı sağlayacağı umut edilmiştir. Ancak çalışma makaleden ibaret olduğu için belli kişilerle sınırlı tutulması gibi bir zorunluluk ortaya çıkmıştır. Bu bağlamda özellikle Hâkim en-Nîsâbûrî (ö. 405/1014) tarafından hadis uydurmakla itham edilen kadılar ele alınmıştır. Tespit edebildiğimiz kadarıla Hâkim en-Nisâbûri, el-Medhal ila ma 'rifeti's-sahîh mine's-sakîm ve tebyîn mâ eşkele min esmâi 'r-ricâl fì's-sahîhayn (Kitabın ismi ile ilgili bk. Kandemir, 1997: 191) adlı eserinde beş kadıyı hadis uydurmakla itham etmiştir. Bunlar Mansûr b. Abdülhamid (ö. ?) İbn 'Ulâse (ö. 168/785), Nûh b. Ebî Meryem ö. 173/789) Nûh b. Derrâc (ö. 182/799) ve Ebû'l-Bahterî Vehb b. Vehb (ö. 200/816)'tir. Nûh b. Ebî Meryem tek başına müstakil bir çalışmaya konu olabilecek kadar detaylı ve önemli olduğundan burada zikredilmemiştir.

Bu çalışmada yukarıdaki kadılar, hadis ilmi ve özellikle hadis rivayeti bağlamında zikredilen sorular ve sorunlar çerçevesinde ele alınmaya gayret gösterilmiştir. Buna göre zikredilen kadılar örneğinde kadıların hadis rivayetindeki katkıları belirlenmeye, hadis râvisi olarak kabul edilip edilmedikleri gibi sorular cevaplanmaya çalışılmıştır. Bunun yanı sıra hadis münekkitlerinin söz konusu kadılarla ilgili ortaya koydukları tenkitlerinde ittifak edip etmedikleri ele alınmıştır. Aynı şekilde Hâkim en-Nîsâbûrî’nin söz konusu kadılarla ilgili iddiası, diğer münekkitlerin bu konudaki görüşleriyle mukayese edilmiştir. Böylelikle Hâkim en-Nîsâbûrî’nin bu konudaki iddiasının doğruluğu tespit edilmeye çalışılmıştır. Ancak kadıların tercemelerine geçmeden önce genel olarak hadisçilerin kadılığa bakışları ve kadıların hadisle ilişkilerini özet bir şeklide sunmakta fayda mülahaza edilmiştir.

\section{A) Hadisçilerin Kadılığa Bakışları ve Kadıların Hadis Rivayetiyle İlişkileri}

Hadis münekkitlerinin, genel olarak kadılık vazifesine pek de olumlu bakmadıkları görülmektedir. Şüphesiz bunun sebebi farklı açılardan ele alınabilir. Ancak bunun temel nedeninin, kadılıkla meşgul olanların zaman içerisinde hadisten uzaklaştıkları, buna bağlı olarak da zabt sorununa maruz kalmaları olduğu söylenebilir. Başka bir ifadeyle kadılıkla meşgul olanların 
üstlendikleri görev sebebiyle zaman içerisinde hafiza bozukluğuna uğradıkları düşünülmüştür. Bu bağlamda İbn Ebî Leylâ (ö. 148/765) ve Şerîk b. Abdullah en-Nehaî (ö. 177/794) ile ilgili söylenenler bunun apaçı delilidir denilebilir. Rivayete göre İbn Ebî Hâtim (ö. 327/938) İbn Ebî Leylâ'nın durumunu babası Ebû Hâtim'e (ö. 277/890) sormuş, babası da "Onun konumu sıdk makamıdır, kadılıkla iştigal etti, hafiza bozukluğuna uğradı, yalancılıkla itham edilmez, çok hata yapması hoş karşılanmamış, hadis yazılır, ancak delil olamaz" demiştir (İbn Ebî Hatim, 1952: 7, 323). Aynı şekilde Şerîk b. Abdullah en-Nehaî de vera sahibi fakih ve bid'at ehline karşı çok şedid olarak tavsîf edilmiştir. Hadis âlimleri onu tebcil etmiştir. Ancak kadılık görevini üstlendikten sonra hadisleri alınmamaya başlanmıştır. Nitekim Vekî' "Şerîk kadı olduktan sonra ondan hadis yazmadım" diyerek bu gerçeğe işaret etmiştir (Zehebî, 1985: 8, 204).

Kaynaklarda hadis âlimlerinin kadılığ kabul etmek istemedikleri ve onu zem ettiklerine dair birçok nakil bulmak mümkündür (Vekî', 1947: 1, 25-28). Söz gelimi Beyhakî’nin (ö. 458/1066) nakline göre Abdullah b. Vehb'e (ö. 197/813) Misır kadıllğg teklif edilmiştir. Ancak İbn Vehb kendini deliliğe vurarak eve kapatmıştır. Kendisine niye bunu kabul etmediğini söyleyen kişiye "Aklını mı yitirdin! Bilmiyor musun kadılar kıyamet gününde sultanlarla, âlimler ise Peygamberlerle haşredilecektir" şeklinde cevap vermiştir (Beyhakî, 1344: 10, 169). Konuyla ilgili Ahmed b. Hanbel'den (ö. 241/855) dikkat çekici bir nakil rivayet edilmiştir. Rivayete göre Ahmed b. Hanbel'e Vekî'’i mi yoksa Yahyâ b. Saîd'i mi daha çok sevdiği sorulmuş, Ahmed b. Hanbel de Vekî‘'i daha çok sevdiğini söylemiştir. Bunun sebebini de "Vekî' Hafs b. Ğiyâs'ın arkadaşıydı, ancak Hafs kadılık görevini üstlenince Vekî‘ onu terk etti, Yahyâ b. Saîd ise onunla ilişkisini kesmeyip arkadaşlığına devam etti” şeklinde açıklamıştır (Zehebî, 1985: 9, 144).

Kadılarla ilgili dikkat çeken bir başka konu da verdikleri fetvalarda hadislerden daha çok sahâbe ve tâbiîn fakihlerin uygulamalarına müracaat etmeleridir. Bundan yola çıkılarak kadıların fetvalarında metinden ziyade, uygulamanın daha çok belirleyici olduğu söylenebilir (Koç, 2019: 126). Bu bağlamda hadislerin, kadıların vermiş olduğu fetvalarda ne kadar etkili olduğu; üzerinde durulması gereken önemli bir mevzu olarak görülmektedir. Hal böyleyken bu alanda yapılacak müstakil çalışmalarla hadis ile kadıların fetvaları arasındaki ilişki izaha kavuşturulabilecektir.

Kadıların fakîh ve râvi kimliklerinin farkını Buhârî'de bulmak mümkündür. Mesela Buhârî Sahîh'inin bab başlıklarında bazı kadıların fikhi görüşlerine yer vermiştir (Buhârî: "Vudû", 69; "Savm", 25; "Talâk", 5). Ancak bab başlıklarında yer verdiği kadıların çoğundan hiç hadis tahrîc etmemiş veya çok az tahrîc etmiştir. Bu da Buhârî'nin söz konusu kadıların fikhî müktesebatını hadislerine tercih ettiğini göstermektedir (Koç, 2019: 128).

Kadıların hadis rivayeti ile ilgili önemli bir husus da, Kadı Şüreyh (ö. 80/699 [?]), İbn Şübrüme (ö. 144/761) ve İbn Ebî Leylâ gibi meşhur kadıların durumudur. Zira bu kadıların fetvaları çok yaygın, hadis rivayetleri ise azdır. Ancak Şa'bî (ö. 104/722) gibi bazı istisnaların olduğu da bir hakikattir. Zira Şa'bî hem fetvayla hem de hadis rivayetiyle bilinen bir şahsiyettir. Abdurrahman b. Ebî Leylâ ve Saîd b. Cübeyr (ö. 94/713 [?]) ise daha çok hadis rivayetiyle ön plana çıkmıştır. Bu gerçeklikten hareketle fetva ve fikıh alanında meşhur olan kadıların, hadis rivayetiyle az meşgul oldukları ve hadis rivayetinde pek de ön plana çıkmadıkları görülmektedir (Koç, 2019: 134).

\section{B) Hâkim en-Nîsâbûrî’nin Hadis Uydurmakla İtham Ettiği Kadılar}

Hadisçilerin kadılığa bakışları özet bir şeklide verildikten sonra Hâkim en-Nîsâbûrî’nin hadis uydurmakla itham ettiği kadıların durumlarına geçilebilir. Burada kadılar, kronolojik sıralamaya göre ele alınacaktır.

\section{Mansûr b. Abdülhamid b. Râşid el-Cezerî el-Mervezî (?)}

Ebû Reyâh Mansûr b. Abdülhamid el-Cezerî Ammâr b. Yâsir'in mevlasıdır. İbn Ebî Hâtim'e göre Mansûr b. Abdülhamid; Ebû Ümâme, Enes b. Mâlik, Abdullah b. Ömer, Ebû Hüreyre, Tâvus, Mekhûl, Katâde ve başkalarından rivayette bulunmuştur. Ondan da Seleme b. Süleyman el-Mervezî, 
Muâz b. Esed el-Mervezî ve Abdullah b. Mûsâ el-Hânî gibi râviler rivayette bulunmuştur (İbn Ebî Hatim, 1952: 8, 175). Mansûr b. Abdülhamid Merv'de kadılık yapmıştır.(Ebû Nuaym, 1984, s. 149) Hâkim en-Nîsâbûrî ise Mansûr'u el-Cezerî nisbsiyle tavsif etmiş ve oranın kadısı olduğunu söylemiştir (Hâkim en-Nîsâbûrî, 2009: 1, 230).

Kaynaklarda Mansûr b. Abdülhamid'in vefat tarihi ile ilgili sadece Zehebî'nin Târîhü 'lİslâm adlı eserinde iki farklı tarih zikredilmiştir. Birincisi hicri 171-180, ikincisi ise 191-200 aras1 tarihlerdir (Zehebî, 2003: 4, 750-1216). Ancak Zeheb'i'nin zikrettiği bu iki tarih de problemlidir. Zira kaynaklarda, Mansûr b. Abdülhamid'in Sahabîlerden naklide bulunduğu zikredilmiştir. Bu durumda vefat tarihinin en az hicri 150'den önce olması gerekmektedir. Bundan dolayı biz de Mansûr b. Abdülhamid'in ölüm tarihini yazmamayı uygun gördük.

Hâkim en-Nîsâbûrî "Enes ve Ebû Ümâme el-Bâhilî̀'den mevzu rivayetleri nakletmiştir" diyerek Mansûr b. Abdülhamid'i hadis uyudurmakla itham etmiştir (Hâkim en-Nîsâbûrî, 2009: 1, 230). Buna karşın Yahyâ b. Maîn, Ahmed b. Hanbel, Buhârî ve Ebû Hâtim gibi hadis münekkitlerinin görüşlerine rastlamadık. İbn Ebî Hâtim eserinde onu tercemesine yer vermiş, ancak cerhi ve ta'dîli ile ilgili herhangi bir ifadede bulunmamıştır (İbn Ebî Hatim, 1952: 8, 175). İ̉n Adî ise Mansûr b. Abdülhamid'in tercmesine yer vermemiştir.

Tespit edilebildiği kadarıyla Mansûr b. Abdülhamid'in tercemesine yer veren ve onu tenkit eden ilk münekkit İbn Hibbân'dır (ö. 354/965). Dolayısıyla Mansûr'un rivayetinin İbn Hibbân'dan önce pek bilinmediği, ancak hicri dördüncü asırda rivayet edilmeye başlandığı söylenebilir. Ayrıca Mansûr'un rivayetin merkezi olan Şâm'1 terk edip Belh'e gitmesi de onun rivayetlerinin bilinmemesine sebep olmuş olabilir.

İbn Hibbân'ın Kitâbü'l-Mecrûhîn'inde verdiği bilgilere göre Mansûr b. Abdülhamid Belh'e gelmiş ve sahabi olan Ebû Ümâme el-Bâhilî’den (ö. 86/705) rivayette bulunmuştur. İbn Hibbân akabinde Muhammed $b$. Abdullah el-Cüneyd $\rightarrow$ Abdullah b. Mûsâ el-Hânî’nin şöyle dediğini nakletmiştir: "Mansûr b. Abdülhamid Ebû Ümâme'den yaklaşık üç yüz hadisten oluşan bir nüshay1 rivayet etmiştir, bunların çoğu uydurma olup hiçbir asılları bulunmamaktaydı. İbn Hibbân "Ondan rivayet etmek helal değildir, burada zikretmemin sebebi tanınsın diyedir, zira arkadaşlarımız onun hadislerini yazmışlardı" (İbn Hibbân, 1396: 3, 39). Aynı şeklide İbn Asâkir de ondan rivayette bulunmanın helal olmadığını söylemiştir (Zehebî, 2003: 4, 1216).

Ebû Nuaym (ö. 430/1038) "Mansûr b. Abdülhamid el-Mervezî, Merv'in kadısıydı, Ebû Rebâh künyesiyle bilinirdi. Enes ve Ebû Ümâme'den batıl şeyler rivayet etmiştir" şeklinde tanıtmıştır (Ebû Nuaym, 1984: 149). Zehebî de onun sika olmadığını söylemiştir (Zehebî, 2003: 4, 1216).

İbnü'l-Cevzî, Mansûr b. Abdülhamid ile ilgili İbn Hibbân'ın görüşünü aktarmakla yetinmiştir (İbnü'l-Cevzî, 1986: 3, 139). Aynı şeklide İbn Hacer de onunla ilgili İbn Hibbân, Hâkim en-Nîsâbûrî ve Ebû Nuaym'ın görüşlerini aktarmış, ancak kendisi herhangi bir kanaat belirtmemiştir (İbn Hacer, 2002: 6, 97).

\subsection{Hadis Literatüründe Mansûr b. Abdülhamid'in Rivayetleri}

Mansûr b. Abdülhamid'in rivayetleri temel hadis kaynaklarında yer almamaktadır. Bu da Mansûr b. Abdülhamid'in hadis râvisi olarak pek de ön plana çıkmadığını göstermektedir. Bu bağlamda ilk dönem münekkitlerinin onun hakkında kanaat belirtmemelerinin sebebi de bu olsa gerektir.

Mansûr b. Abdülhamid'den nakledilen çok az rivayet bulunmaktadır. Bunlardan, Hatîb elBağdâdî Abdulgaffâr $b$. Muhammed $\rightarrow$ Muhammed $b$. Abdullah eş-Şâfiî $\rightarrow$ Muhammed Hasan elBelhî $\rightarrow$ Yahyâ b. Hâlid $\rightarrow$ Mansûr b. Abdülhamid $\rightarrow$ Enes b. Mâlik isnadıyla nakledilen rivayete göre Hz. Peygamber şöyle buyurmuştur: "Beni gören, beni göreni gören, beni göreni göreni gören olduğu müddetçe ümmetim hayır içerisinde olacaktır." Râvi "Hz. Peygamber bunu üç sefer tekrar 
etti” demiştir (Hatîb el-Bağdâdî, 2002: 2, 583). Görüldüğü gibi Mansûr b. Abdülhamid söz konusu rivayeti $\mathrm{Hz}$. Enes'ten rivayet etmiştir.

$\mathrm{Bu}$ rivayet Mansûr b. Abdülhamid'in yer almadı̆̆ 1 isnadla Taberânî tarafindan da nakledilmiştir. Taberânî rivayeti Muhammed b. Ahmed el-Mukrî $\rightarrow$ Dînâr b. Abdullah $\rightarrow$ Enes b. Mâlik isnadıyla rivayet etmiştir. Ancak rivayet "Beni gören, beni göreni gören, beni göreni göreni görene müjdeler olsun” şeklindedir (Taberânî, t.y.: 6, 171). İbn Adî’ye göre isnadda yer alan Dînâr b. Abdullah Enes b. Mâlik'ten batıl rivayetleri nakletmiş ve bu manada Enes'ten rivayette bulunanların tamamı meçhul kişilerdir (İbn Adî, 2013: 9, 556). Dolayısıyla Mansûr b. Abdülhamid'in tarikiyle gelen rivayetin zayıf olduğu söylenebilir. Bunun yanı sıra muhteva bakımından Mansûr $b$. Abdülhamid'in rivayetine yakın olan bir rivayet, sahabi Vâsile b. el-Eska' tarafindan nakledilmiştir (Ebû Nuaym, 1988: 1, 15; Taberânî, 1984: 1, 452).

Mansûr b. Abdülhamid'in rivayetlerini tahrîc eden diğer muhaddis Beyhakî'dir. Mansûr b. Abdülhamid $\rightarrow$ Enes b. Mâlik isnadıyla nakledilen bir rivayete göre Hz. Peygamber şöyle buyurmuştur: "Allah, sabah namazını kılıp sonra ahiret gününde Allah'ın rızasını umarak bir hastayı ziyaret eden kişiye merhamet etsin! Allah o kişinin attığı her adımın karşıllğında bir sevap yazar ve bir günahını siler. O kişi hastanın yanında oturduğunda Allah onu sevap içerisinde gark edecektir" (Beyhakî, 2003: 11, 409). Beyhakî'nin tahrîc ettiği bu rivayetin, şâhid ve mutâbiine rastlayamadık. Dolayısıyla söz konusu rivayetin bu haliyle Mansûr b. Abdülhamid'in teferrüdü olduğu söylenebilir.

İbn Asâkir'in Mansûr b. Abdülhamid $\rightarrow$ Enes b. Mâlik isnadıyla naklettiği rivayete göre Hz. Peygamber bir gün sabah namazını kıldı, sonra bir topluluğa uğradı. Onlara selam verdikten sonra nasıl sabahladıklarını sordu. Topluluk da mümin olarak sabahladıklarını söylediler. Hz. Peygamber üç sefer tekrar etti, topluluk da her üçünde de mümin olarak sabahladıklarını ifade ettiler. Bunun üzerine Hz. Peygamber onlara imanın ne olduğunu söyledi. Onlar da imanın belaya sabretmek ve genişlikte şükretmek olduğnu söylediler. Ayrıca kadere de iman ettiklerini dile getirdiler. Hz. Peygamber onların bu sözlerinin akabinde "Kabe'nin Rabbine yemin olsun ki bunlar mümindirler" dedi. İbn Asâkir rivayetin metninin ve isnadının garip olduğunu söylemiştir (İbn Asâkir, 2000: 1, 153).

Mansûr b. Abdülhamid'in isnadında yer aldığı bir rivayet de Sa 'lebî (ö. 427/1035) tarafindan tahrîc edilmiştir. Söz konusu rivayette bir a'rabî kadının Hz. Peypamer'in haberi olmadan arkasında namaz kıldığını; Hz. Peygamber de "Muhakkak cehennem, onların hepsine vâ'dolunan yerdir. Cehennemin yedi kapısı vardır. Onlardan her kapı için birer gurup ayrılmıştır" (Hicr, 43-44) ayeti okuyunca kadının bayıldğı zikredilmiştir. Sa 'lebî rivayeti Mansûr b. Abdülhamid $\rightarrow$ Enes $b$. Mâlik isnadiyla zikretmiştir (Sa'lebî, 2002: 5, 342). İbn Receb de söz konusu hadisi Sa'lebî'nin tahrîc ettiğini söylemiş ve şu değerlendirmede bulunmuştur: "Bu hadis merfu olarak sahih değildir. Ayrıca İbn Hibbân da Mansûr b. Abdülhamid'den rivayette bulunmak helal olmadığını söylemiş̧tir" (İbn Receb, 1988: 81). Dolayisiyla Mansûr b. Abdülhamid'in bu rivayetinin de problemli olduğu aşikârdır.

Rivayetleri problemli olduğu anlaşılan Mansûr b. Abdülhamid, İbn Hibbân ve Hâkim enNîsâbûrî tarafından hadis uydurmakla itham edilmiştir. Daha sonra gelenler de İbn Hibbân ve Hâkim'in görüsslerini temel alarak Mansûr b. Abdülhamid'i cerh etmişlerdir. Bunun yanı sıra ricâl ilminde otorite kabul edilen âlimlerin ise Mansûr $b$. Abdülhamid hakkında herhangi bir görüşlerine rastlayamadık. Bundan yola çıkılarak Mansûr b. Abdülhamid'in ilk dönem hadis münekkitleri nezdinde hadis râvisi olarak telakki edilmediği söylenebilir.

\section{(ö. 168/785)}

2. Ebû'l-Yesîr Muhammed b. Abdullah b. 'Ulâse el-Ukaylî el-Cezerî el-Harrânî el-Kâdî

Harranlı olan İbn 'Ulâse ve Ebû'l-Yesîr el-Kâdî Muhammed b. Abdullah el-Cezerî'dir. Ancak kaynaklarda daha çok İbn 'Ulâse künyesiyle kaydedilmiştir. İbn 'Ulâse; Abdülkerim el- 
Cezerî, Ali b. Büzeyme Abde b. Ebî Lubâbe, Ubeydullah b. Ömer, el-Evzâî ve başkalarından hadis almıştır. Ondan da Abdullah b. Mübarek, Vekî‘ ve Amr b. Husayn başta olmak üzere birçok kişi rivayette bulunmuştur (Zehebî, 2003: 4, 498). Mehdî, onu Bağdat'a ve daha sonra “Askerü'l-Mehdî" olarak meşhur olacak yere Âfiye b. Yezîd'le beraber kadı olarak atamıştır (Vekî', 1947: 3, 251). Ayrıca bazı kaynaklarda hem Mansûr'un hem de Mehdî'nin atadığı kadı olarak da geçmektedir (İbn Adî, 2013: 7, 454). İbn 'Ulâse Süfyân es-Sevrî'nin arkadaşı olarak bilinmektedir. Ancak Süfyân ona kadılık görevini kabul ettiği için kızmış ve ilişkisini kesmiştir. Nitekim Süfyân ona "Balık avlayıp Kûfe sokaklarında satsaydın bu görevden daha iyiydi" (Hatîb el-Bağdâdî, 2002: 3, 379) diyerek tepkisini ortaya koymuştur.

Hâkim en-Nîsâbûrî İbn 'Ulâse'yi hadis uydurmakla itham etmiştir. Kendisi “İbn 'Ulâse; Evzâî, Husayf el-Cezerî ve Nadr b. Arabî’den uydurma hadis rivayet ederdi. Onun rivayetlerinin medarı Amr b. Husayn el-Ukaylî’dir” demiştir (Hâkim en-Nîsâbûrî, 2009: 201). Aynı şekilde onu zâhibü'l-hadîs olarak tavsîf etmiş ve Müslümanların imamlarından münker hadis rivayet ettiğini iddia etmiştir (es-Siczî, 2006: 67). Bununla beraber İbn 'Ulâse ile ilgili hadis münekkitlerinden farkl1 değerlendirmeler gelmiştir. Söz gelimi İbn Sa ‘d "İnşaallah sikadır” (İbn Sa'd, 1990: 7, 234), Yahyâ b. Maîn de "Muhammmed b. "Ulâse sikadır" demiştir (Ebû Zekeriyyâ el-Bağdâdî Yahyâ b. Maîn, 1979: 3, 176). Ebû Zür'a onun için "salih" ifadesini kullanmıştır (İbn Ebî Hatim, 1952: 7, 302) İbn Adî ise onun teferrüd ve sikalara muhalefet ettiği bazı rivayetlerini verdikten sonra " $O$, hasenü'lhadîstir, umut ediyorum ki onda bir beis yoktur" demiştir (İ̉bn Adî, 2013: 7, 456). İbn Hacer, İbn 'Ulâse için "Sadûktur, hata yapar" ifadeleri kullanmıştır.

Hatîb Bağdâdî’nin naklettiğine göre Hafiz Ebû'l-Feth Muhammed b. Hüseyin el-Ezdî (ö. 369/980) "Ebû'l-Yesîr benim yanımda vâhü'l-hadîstir, Evzâî'den naklettiği rivayetleri yazmak helal değildir" demiştir. Ayrıca Ebû'l-Feth Buhârî'nin "hıfzı problemlidir" ifadesi bağlamında şöyle demiştir: "Bu ifadenin Buhârî'ye ait olduğu konusunda ikna olmuyoruz, Muhammed b 'Ulâse'nin rivayetleri onun kizbine delalet etmektedir. Ayrıca kendisi, Evzâ̂'’nin rivayetlerinde illet ve itham oluşmasına sebep olan kişilerdendir" (Hatîb el-Bağdâdî, 2002: 3, 379). Şüphesiz el-Ezdî'nin, rivayetlerinin onun yalancı olduğuna delalet etmesini tespit etmesi önemlidir. Yani rivayetinden hareketle râvi ile ilgili bir kanaate varılmıştır. Bu da cerh-ta'dîlde önemli bir ilkedir (Konuyla ilgili geniş bilgi için bk. Topgül, 2019). Zira rivayetten hareketle râvi hakkında bir sonuca gitmek râvi değerlendirilmesinde pratiğin ne kadar önemli olduğunu göstermektedir. Aynı şekilde râvilerle ilgili hadis münekkitlerinin görüşlerinin test edilebilmesinin mümkün olabileceğini de ortaya koymaktadır.

Hatîb Bağdâdî ise, Ebû'l-Feth'in İbn 'Ulâse konusunda ifrata kaçtığını söylemiştir. Ayrıca Hatîb'e göre İbn 'Ulâse'nin tenkit edilmesinin sebebi, ondan rivayette bulunan ve kezzâb olan Amr b. Husayn'dir. Yani İbn 'Ulâse'nin rivayetinde var olan hataların ondan değil, onun râvisi olan ve yalancı kabul edilen Amr b. Husayn'dan olduğunu söylemiştir. Nitekim Hatîb "İbn 'Ulâse'ye gelince İbn Maîn onu sika olarak tavsîf etmiştir, hadis imamlarından hiçbirisinin İbn Maîn'e muhalefet ettiğini bilmiyorum" diyerek İbn 'Ulâse ile ilgili kanaatini belirtmiştir (Hatîb el-Bağdâdî, 2002: 3, 379). Ancak Zehebî "Sen Buhârî'nin 'onun hıfzı problemlidir' sözünü naklettin” diyerek Hatîb'i tenkit etmiştir (Zehebî, 1963: 6, 203).

Buhârî ve Ukaylî İbn 'Ulâse'nin hıfzının problemli olduğunu belirtmiş (Buhârî, 1362: 1, 132; Ukaylî, 2008. 4, 91), Ebû Hâtim ise "hadisi yazılır, ancak delil olamaz" demişlerdir (İbn Ebî Hatim, 1952: 7, 302). Bununla beraber Buhârî'nin, İbn 'Ulâse'nin tercemesi bağlamında İbn 'Ulâse $\rightarrow$ Hişâm $\rightarrow$ İbn Sirîn $\rightarrow$ Ebû Hüreyre isnadıyla gelen rivayete göre Hz. Peygamber şöyle buyurmuştur: "Mebrûr olan haccın mükafatı ancak cennettir." Buhârî daha sonra Abdülkadir $\rightarrow$ Hişâm $\rightarrow$ Ömer b. Muhammed $\rightarrow$ babası $\rightarrow$ Ebû Hüreyre isnadıyla gelen rivayeti vermiş ve bu tarikin daha sahih olduğunu ifade etmiştir. $\mathrm{Bu}$ da İbn 'Ulâse'nin "Sülûkü'l-câdde" ile rivayette bulunduğunu göstermiştir. Bu da râvinin vehminden kabul edilmektedir ("Sülûkü'l-câdde" terimi ile ilgili bk. Düzenli, 2013). 
İbn Hibbân (ö. 354/965) İbn 'Ulâse ile ilgili "sika ve sebt râvilerden uydurma ve mu'dal (Mu'dal'ın tanımı için bk. Aydınlı, 2009: 194) rivayetleri nakleden râvilerdendir, tenkit amacının dışında ondan söz etmek ve hayret etmek bağlamının dışında onun rivayetlerini yazmak helal değildir" demiştir (İbn Hibbân, 1396: 2, 279). Ebû Nuaym de onu münker rivayetleri nakletmekle suçlamış (Ebû Nuaym, 1984: 142). Dârekutnî onu "zayıf ve metrûku'l-hadîs" olarak nitelemiştir (Dârekutnî, 2004: 1, 410).

Yukarıda değinildiği gibi Hatîb el-Bağdâdî, İbn 'Ulâse'nin tenkid edilmesine yol açan asıl sebebin kendisi olmadığını, ondan rivayette bulunan ve kezzâb olarak kabul edilen Amr b. Husayn olduğunu ifade etmiştir. Hâtib'in bu tespitinin önemli olduğunu belirtmek isteriz. Zira İbn 'Ulâse'nin cerhi bağlamında nakledilen birçok rivayet Amr b. Husayn $\rightarrow$ İbn 'Ulâse şeklindedir. Söz gelimi İbn Hibbân (İbn 'Ulâse'yi en ağır ifadelerle cerh eden kişidir), İbn 'Ulâse'nin cerhi bağlamında üç rivayet nakletmiştir, her üçünün isnadı Amr b. Husayn $\rightarrow$ İbn 'Ulâse şeklindedir (İbn Hibbân, 1396: 2, 280). Aynı şekilde İbn Adî, İbn 'Ulâse'nin cerhine sebep olan yedi rivayet nakletmiştir. Bunların içerisinde iki rivayet Amr b. Husayn $\rightarrow$ İbn 'Ulâse isnadiyla nakledilmiştir (İbn Adî, 2013: 7, 454-455). Hatîb'in tespitinin Zehebî tarafından da benimsendiği görülmektedir. Zira Zehebî "Ebû Ya'lâ elMevsılî $\rightarrow$ Amr b. Husayn $\rightarrow$ İbn 'Ulâse $\rightarrow$ Husayf $\rightarrow$ Mücâhid $\rightarrow$ Ebû Hüreyre isnadıyla merfu olarak şu rivayeti nakletmiştir: "Kim ümmetimden dinleri konusunda faydalı olan kırk hadisi ezberlerse kıyamet gününde âlimlerle haşrolunur. Âlimin âbide üstünlüğü yetmiş derecedir, her iki derece arasında ne kadar olduğunu ancak Allah bilir." Zehebî rivayetin akabinde "Zahir olan odur ki bu rivayet İbn Husayn'ın uydurmasıdır" diyerek rivayetteki problemin Amr b. Husayn olduğunu ifade etmiştir (Zehebî, 1963: 6, 203). Aynı şeklide Amr b. Husayn $\rightarrow$ İbn 'Ulâse $\rightarrow$ Evzâî $\rightarrow$ Zührî $\rightarrow$ Ebû Hüreyre isnadıyla merfu olarak gelen "Hased ancak ilim ve duada gereğinden fazla uzatmakta vardır" rivayeti için İbn Adî "Bu münker bir hadistir, Evzâî'den ancak İbn 'Ulâse rivayet etmiştir." diyerek İbn 'Ulâse'yi eleştirmiştir (İbn Adî, 2013: 7, 454). Ancak Zehebî "Umulur ki bu rivayet Amr'ın afetindendir, zira o, metruktür" diyerek rivayetteki problemin İbn 'Ulâse'den değil, Amr b. Husayn'dan kaynaklandığına işaret etmiştir (Zehebî, 1963: 6, 202). Şüphesiz İbn 'Ulâse'ye yapılan tenkitlerin tamamını Amr b. Husayn'e bağlamak çok iyimser bir düşünce olacaktır. Ancak İbn 'Ulâse'nin cerh edilmesinde, yalancı olan Amr b. Husayn'ın önemli etkisinin olduğu da görülmektedir.

\subsection{Hadis Literatüründe İbn 'Ulâse'nin Rivayetleri}

Hadis literatürü tarandığında İbn 'Ulâse'nin çok rivayeti olmadığı görülmektedir. Tespit edebildiğimiz kadarıla İbn 'Ulâse'nin rivayetleri Buhârî ve Müslim'in Sahîh'lerinde yer almamaktadır. Bununla beraber Ebû Dâvud bir (Ebû Dâvud: Hudûd, 24), İbn Mâce iki (İbn Mâce: Tahâret, 53, 444; İkâmetü's-Salât, 49, 990), Nesâi iki (Nesâî: İlim, 21; Recm, 14) ve Ahmed b. Hanbel iki (Ahmed b. Hanbel, 2001: 3, 327; 25, 281) rivayet İbn Ulâse'den tahrîc etmişlerdir. Bu rivayetlerden bir tanesi her üç âlim tarafindan da nakledilmiştir. Ayrıca Ahmed b. Hanbel'in Müsned'inin muhakkikleri İbn 'Ulâse'nin rivayetlerini zayıf kabul etmişler, gerekçe olarak İbn 'Ulâse'yi göstermişlerdir. Bunun yanı sıra Abdürrezzâk es-San'ânî'nin (ö. 211/826-27) Müsannef'inde İbn 'Ulâse'nin iki fetvası bulunmaktadır (es-San'ânî, 2010: 2, 42; 10, 89). İbn Ebî Şeybe'nin (ö. 235/849) Müsannef'inde de dört maktû nakil bulunur her dört haber de fetvadan ibarettir (İbn Ebî Şeybe, 2009: 2, 112-528; 9, 24-408).

Aynı şekilde Dârekutnî (ö. 385/995) el-illel adlı eserinde İbn 'Ulâse'nin tenkidi bağlamında iki rivayet nakletmiştir. Mâlik b. Yehâmir (ö. 70/690) $\rightarrow$ Muâz (ö. 17/638) isnadıyla yer alan birinci rivayete göre Hz. Peygamber şöyle buyurmuştur: "Allah, kulun üzerinde bulunan nimetini artırırsa insanların o kula karşı sıkıntıları da fazla olacaktır. Kim insanların bu sıkıntılarına tahammül etmezse Allah'ın kendisine vermiş olduğu nimetleri yok olmaya maruz bırakmıştır." Dârekutnî söz konusu rivayetin iki isnadını zikretmiştir. Birincisi "Muhammed b. 'Ulâse $\rightarrow$ Sevr b. Yezîd $\rightarrow$ Halid b. Me‘dân $\rightarrow$ Mâlik b. Yehâmir $\rightarrow$ Muâz" şeklindedir. İkincisi ise "Ahmed b. Me‘dân $\rightarrow$ Sevr b. Yezîd 
$\rightarrow$ Muâz" tarikidir. Dârekutnî akabinde "Bu sabit olmayan zayıf bir hadistir" diyerek görüşünü ifade etmiştir (Dârekutnî, 2011: 3, 31).

Muhammed b. Sîrîn (ö. 110/729) $\rightarrow$ Ebû Hüreyre isnadıyla gelen ikinci rivayete göre Hz. Peygamber şöyle buyurmuştur: "Bazıları ya namazda gözlerini semaya dikmekten vaz geçer ya da gözleri kör edilecektir." Bu rivayet "Muhammed b. 'Ulâse $\rightarrow$ Hişâm $\rightarrow$ Muhammed b. Sîrîn $\rightarrow$ Ebû Hüreyre" şeklindedir. Fudayl b. İyâd ise İbn 'Ulâse'ye muhalefet etmiş ve rivayeti Hişâm $\rightarrow$ Muhammed b. Sîrîn $\rightarrow$ isnadıyla mürsel olarak nakletmiştir. Aynı şekilde Eyyûb es-Sahtîyânî, Hâlid el-Hezzâ - İbn Avn $\rightarrow$ Muhammed b. Sîrîn isnadıyla nakledilmiştir. Dârekutnî "Kim İbn Avn'dan muttasıl olarak rivayet etmişse vehme düşmüştür, sahih olanı Mürsel olanıdır" diyerek İbn 'Ulâse'nin Muhammed b. Sîrîn'den muttasıl rivayette bulunarak vehme düştüğüne işaret etmiştir (Dârekutnî, 2011: 4, 85). ${ }^{1}$

Yukarıdaki rivayet ve değerlendirmeler, İbn 'Ulâse'nin naklettiği bazı rivayetlerinde hata ettiğini göstermektedir. Ancak bu hatalar İbn 'Ulâse'nin zabtının zayıflığı bağlamında değerlendirilmelidir. Nitekim Buhârî'nin görüşü de buna delalet etmektedir. Hal böyleyken Ebû'lFeth el-Ezdî, İbn Hibbân (ö. 354/965) ve Hâkim en-Nîsâbûrî gibi bazı âlimlerin "İbn 'Ulâse yalancıdır, ondan rivayet etmek helal değildir" gibi değerlendirmelerinin çok ağır ve tenkide açık olduğu görülmektedir. Bununla beraber ricâl konusunda otorite olan Yahyâ b. Maîn'in onu sika olarak nitelemesinin onun yalancı olmadığını göstermesi açısından önemli olduğunu düşünüyoruz.

\section{Ebû Muhammed Nûh b. Derrâc en-Nehaî el-Kûfî (ö. 182/799)}

Hâkim en-Nîsâbûrî "Sika râvilerden uydurma rivayetleri naklederdi" diyerek tenkit ettiği (Hâkim en-Nîsâbûrî, 2009: 1, 231) Nûh b. Derrâc, Zehebî tarafından fakih ve müctehid olarak nitelenmiştir. Nûh b. Derrâc, fikıh ilmini Ebû Hanîfe (ö. 150/767) ve İbn Şübrüme'den (ö. 144/761) almıştır. Aynı şekilde A'meş’ten (ö. 148/765) ve İbn Ebî Leylâ'dan (ö. 148/765) da nakilde bulunmuştur. Kendisinden de Saîd b. Mansûr, Ebû Nuaym Dirâr b. Sürad, Ali b. Hücr, Muhammed b. Sabbâh ve başkaları rivayette bulunmuştur (Zehebî, 2003: 4, 990). Nûh b. Derrâc, Kâsım b. Ma'n'ın ölümünden sonra Hârûnürreşîd tarafindan Kûfe'nin kadılığına atanmıştır (Vekî', 1947: 3, 182). Kûfe'den sonra Bağdât'1n doğusuna kadı olarak görevlendirilmiştir (Hatîb el-Bağdâdî, 2002: $15,431)$.

Nûh b. Derrâc ve hocası olan İbn Şübrüme arasında geçen bir diyalog onun yetkinliğine işaret etmektedir. Rivayet edildiğine göre İbn Şübrüme bir fetva vermiş, ancak Nûh b. Derrâc ondan fetvasını yeniden gözden geçirip araştırmasını istemiştir. Bunun üzerine İbn Şübrüme fetvasında hata yaptığını fark etmiş ve Nûh b. Derrâc'1 öven bir şiir söylemiştir (el-Fesevî, 1981: 2, 612). Nûh b. Derrâc'ın birçok meselede İbn Ebî Leylâ'nın görüşlerine meylettiği de nakledilmiştir (Vekî', 1947: 2, 182).

Hadis münekkitlerinin, Nûh b. Derrâc ile ilgili yaptığı değerlendirmeler tahkik edildiğinde Yahyâ b. Maîn'nin (ö. 233/848) görüşü temel alınmış ve birçok âlim tarafından tekrar edilmiştir. Yahyâ b. Maîn ise onu yalancı ve habîs olarak nitelemiştir (Yahyâ b. Maîn, 1979: 3, 362). Başka bir ifadesinde de hadisi bilmediğini, Şübrüme ve Şa ‘bî’den garip rivayetleri naklettiğini söylemiştir. Bunun yanı sıra Yahyâ b. Maîn, Nûh b. Derrâc'ın insanlara söylemeden iki yıl âmâ olarak kadılık yaptığını nakletmiştir" (Yahyâ b. Maîn, 1979: 4, 29). Yahyâ b. Maîn'in ifadeleri el-Fesevî (el-Fesevî, 1981: 3, 56), Ukaylî (Ukaylî, 2008: 6, 199) ve İbnü'l-Cevzî (İbnü'l-Cevzî, 1986: 3, 167) gibi âlimler tarafından da dile getirilmiştir.

Yahyâ b. Maîn'den sonra Nûh b. Derrâc ile ilgili en ağır cerh Ebû Dâvud (ö. 275/889) ve Nesâî (ö. 303/915) tarafindan yapılmıştır. Söz gelimi Ebû Dâvud, Nûh b. Derrâc'in hadis uydurduğunu söylemiş (Zehebî, 1963: 7, 52), Nesâi ise onu "metrûkü'l-hadis" lafzıyla cerh etmiştir

\footnotetext{
${ }^{1}$ Söz konusu rivayetin sahih isnadı için bk. (Ahmed b. Hanbel, 2001: 19, 193).
} 
(Nesâî, 1396: 101). Tespit edebildiğimiz kadarıla her iki âlim de cerhlerinin sebebini söylememişlerdir. İbn Hibbân da Nûh b. Derrâc'nn sika râvilerden hadis uydurduğunu söylemiştir. Öyle ki bunu çok yaptığı için rivayetleri isnad veya metinlerinde takdim ve te'hir yapmak suretiyle nakletmek zorunda kalmıştır (İbn Hibbân, 1396: 2, 388). İbn Hibbân tarafindan dile getirilen hususu Ebû Nuaym (ö. 430/1038) da dile getirmiş, o da Nûh b. Derrâc'ın özellikle sika râvilerin münker rivayetlerini naklettiğini vurgulamıştır (Ebû Nuaym, 1984: 151).

Nûh b. Derrâc, başka münekkitler tarafindan da cerh edilmiştir. Ancak diğer âlimler onu yukarıda geçen tenkitlere nazaran daha hafif ifadelerle eleştirmişlerdir. Mesela Buhârî onun için râvilerin zayıflığına delalet eden ليس بذاكل ifadesini kullanmış (Buhârî, 2005: 134), İclî (ö. 261/875), Nûh b. Derrâc'1 daîfü'l-hadîs olduğunu belirtmiş, bununla beraber fakih olduğunu da vurgulamıştır (İclî, 1985: 2, 320). Aynı şeklide Ebû Hâtim er-Râzî (ö. 277/890) de onun kavi olmadığını ifade etmiştir. Ayrıca Ebû Hâtim'e göre Nûh b. Derrâc'ın rivayet ettiği hadisler insanlar tarafindan bilinmiyordu, dolayısıyla insanlar onun rivayetlerine itibar etmezdi (İbn Ebî Hatim, 1952: 8, 484485). Bu da onun münker rivayetlerde bulunduğunu göstermiştir. Öte yandan Ali b. Medînî de (ö. 234/848-49) Nûh'un hadiste zayıf olduğunu söylemiş, ancak kezzâb veya hadis uyduruyor gibi ağır eleştirilerde bulunmamıştır (Hatîb el-Bağdâdî, 2002: 13, 318).

Hadis münekkitlerinin yukarıda geçen ağır cerhlerine karşın, Nûh b. Derrâc'ı sika kabul eden âlimler de olmuştur. Nitekim Muhammed b. Abdullah b. Numeyr (ö. 234/849), Nûh b. Derrâc'1 sika tabiriyle nitelemiştir (Hatîb el-Bağdâdî, 2002: 13, 318). Aynı şekilde Ebû Zür'a da Nûh b. Derrâc'ın Kûfe'nin kadısı olduğunu belirtmiş ve onun için "Umut ediyorum ki, ondan hadis almada bir beis yoktur” demiştir (İbn Ebî Hatim, 1952: 8, 485).

Şüphesiz İbn Numeyr'in görüşü konumuz açısından önemlidir. Zira İbn Numeyr; hafiz, hüccet şeyhü'l-İslâm unvanıyla anılmaktadır. Ayrıca İbn Numeyr, Yahyâ b. Maîn ve Ahmed b. Hanbel'in çağdaşıdır ve iki âlim de onu övmüştür. Öyle ki Kûfe râvileri konusunda Yahyâ b. Maîn ve Ahmed b. Hanbel onun görüşlerine itibar etmişlerdir. Zira kendisi Kûfe'li olduğu için Kûfe râvileri konusunda otorite mesabesinde kabul edilmiştir. (Hayatı için bk. Zehebî, 1985, ss. 11, 445448). Nûh b. Derrâc da Kûfeli olduğuna göre İbn Numeyr'in onunla ilgili yaklaşımı ve onu sika kabul etmesi büyük ehemmiyet arz etmektedir.

Hadis münekkitleri içerisinde İbn Adî’nin (ö. 365/976) ve el-Kâmil fì Duafâi'r-Ricâl aldı eserinin önemi ehlince bilinmektedir (Karagözoğlu, 2014: 99-117). Bu bağlamda İbn Adî söz konusu eserinde Nûh b. Derrâc'ın biyografisine yer vermiş ve Yahyâ b. Maîn, es-Sa'dî ve Nesâî'nin görüşlerini nakletmiş ve Nûh b. Derrâc'ın rivayet ettiği iki nakli tahrîc etmiştir. İbn Adî bu iki rivayetin akabinde şöyle demiştir: "Bu iki rivayetin ilki İbn Ebî Leylâ'nın isnadıyla, ikincisi ise Ebân b. Tağleb isnadıyla Nûh b. Derrâc'tan başka rivayet ettiğini bilmiyorum. Nûh b. Derrâc'ın bu iki hadis dışında da rivayeti vardır, ancak çok değildir. Nûh b. Derrâc hadisi yazılan râvilerdendir" (İbn Adî, 2013: 10, 201). İbn Adî’nin, Nûh b. Derrâc'ın biyografisinde zikrettiği rivayetlerden anlaş1ldığ1 gibi kendisi Nûh b. Derrâc'ı rivayetlerinde teferüd ettiği için tenkit etmiştir denilebilir. Şüphesiz bu da râvinin terkini gerekli kılan yalancılık ve hadis uydurmak gibi ağır bir tenkit değildir.

Muteahhir âlimlerinden Mizzî (Mizzî, 1980: 30, 43-48), Zehebî (Zehebî, 1963: 7, 52) ve İbn Hacer (İbn Hacer, 1326: 10, 482-484) Nûh b. Derrâc ile ilgili geçmiş münekkitlerin görüşlerini aktarmakla yetinmişler, kendileri herhangi bir yorumda bulunmamışlardır.

Nûh b. Derrâc'1n tenkit edilmesi bağlamında dikkat çeken bir husus da onun Ebû Hanîfe'nin öğrencisi ve ehl-i re'y olduğu yaklaşımıdır. Söz gelimi Zekeriya b. Yahyâ es-Sâcî (ö. 307/920) "Nûh b. Derrâc Kûfe'nin kadısıydı, Ebû Hanîfe'den re'y alan kişilerdendir. Muhammed b. İshâk'tan bir takım rivayetler nakletmiş ve bu rivayetlerde teferrüd etmiştir. Nûh b. Derrâc onların (Ehl-i hadis) yanında hiçbir şeydi” demiştir (Hatîb el-Bağdâdî, 2002: 13, 318). Ancak Nûh b. Derrâc'nn ehl-i re'ye mensup olduğu için tenkit edildiğini söylemek zordur. Bunun apaçık delili İbn Adî’nin yaklaşımıdır. Zira İbn Adî özellikle İmam Ebû Hanîfe başta olmak üzere ehl-i re'y âlimlere karşı müteşeddid 
münekkitlerdendir (Ünal, 2010: 191-193). Buna rağmen Ebû Hanîfe'nin talebesi olan Nûh b. Derrâc için hadisi yazılır demiştir.

Tabakâtü'l-Hanefiyye, eserlerinde Nûh b. Derrâc'1n biyografisine yer verilmiştir. İmâm Ebû Hanîfe'nin öğrencisi olduğu, ondan ve Züfer'den fikıh öğrendiği vurgulanmıştır. Ancak hadis münekkitlerinin onunla ilgili beyan ettikleri herhangi bir görüşe değinilmemiştir (el-Kemlâî, 2018: 19, 171).

\subsection{Hadis Literatüründe Nûh b. Derrâc'ın Rivayetleri}

Tespit edebildiğimiz kadarıyla Kütüb-i Sitte müellifleri ve Ahmed b. Hanbel gibi muhaddisler Nûh b. Derrâc'tan hadis tahrîc etmemişlerdir. Bununla beraber Nûh b. Derrâc'1n, Ebû Hanîfe'nin Müsned'inde rivayetlerini bulmak mümkündür. Ayrıca Nûh b. Derrâc bu rivayetlerin tamamını Ebû Hanîfe'den nakletmiştir (el-Hârisî, 2010: 2, 595-596-597-673-676-705). Bununla beraber Nûh b. Derrâc'ın Ebû Hanîfe'den naklettiği bazı rivayetlerde teferrüd ettiği de görülmüştür (el-Hârisî, 2010: 2, 676-704).

Hâkim en-Nîsâbûrî'nin, Nûh b. Derrâc'1 hadis uydurmakla suçladığını daha önce değinilmişti. Buna rağmen kendisi el-Müstedrek ala's-Sahîhayn adlı eserinde ondan iki rivayet tahrîc etmiştir (Hâkim en-Nîsâbûrî, 1990: 3, 155-187).

Nûh b. Derrâc'1n bazı rivayetlerinde sika râvilere muhalefet ettiği görülmüştür. Söz gelimi Safiyye binti Ebî Ubeyd'in rivayetine göre bir adam bakire bir cariye ile zina yaptığını itiraf etmiştir. Bunun üzerine Hz. Ebû Bekir adama celd cezasını uygulamış ve onu Fedek'e sürgüne göndermiştir. $\mathrm{Bu}$ rivayet Mâlik $\rightarrow$ Nâfi $^{\circ} \rightarrow$ Safiyye $\rightarrow \mathrm{Hz}$. Ebû Bekir isnadıyla rivayet edilmiştir. Aynı şekilde Ubeydullah b. Amr da Yahyâ el-Kattân'dan bu isnadla rivayet etmiştir. Fakat Nûh b. Derrâc bu tarike muhalefet ederek söz konusu rivayeti Ubeydullah $\rightarrow$ Nâfi ${ }^{\circ} \rightarrow$ İbn Ömer $\rightarrow$ Hz. Ebû Bekir isnadiyla rivayet etmiştir. Söz konusu rivayetle ilgili Mâlik'in tariki doğru kabul edilmiştir (Dârekutnî, 2011: $1,72)$.

İbn Adî, Nûh b. Derrâc'ın tenkidine sebep olabilecek iki rivayet tahrîc etmiștir. İlk rivayet Muhammed b. el-Hüseyin $\rightarrow$ İsmail b. Mûsâ $\rightarrow$ Nûh b. Derrâc $\rightarrow$ İbn Ebî Leylâ $\rightarrow$ Minhâl $\rightarrow$ Saîd b. Cübeyr $\rightarrow$ Abdullah b. Abbâs isnadiyla nakledilmiştir. Bu rivayete göre Hz. Peygamber hamilelikte li âna başvurmuştur." Yani erkek eşinin hamileliğini başka birisine nispet ettiğinde karıkoca arasında lânetleşme yapılırdı (Li'ânın anlamı için bk. Erdoğan, 2005: 327). İkinci rivayet ise Ahmed b. İshâk $\rightarrow$ İshâk $b$. İbrahim $\rightarrow$ 'İsâm b. Veddâh $\rightarrow$ Nûh b. Derrâc $\rightarrow$ Ebân b. Tağleb $\rightarrow$ Ebû İshâk $\rightarrow$ Umeyre b. Ziyâd isnadıyla verilmiştir. Rivayetin metni şöyledir: "Biz onunla hac ettik, Rabze'den ihrama girmek istediğimizde kendimize şart koşmak istedik. Râvi: "İbn Mes 'ûd bunu bize emretti, ancak o (Nûh b. Derrâc) Hz. Peygamber'in emrettiğini iddia etti” (İbn Adî, 2013: 10, 201). İbn Adî’nin de belirtitği gibi Nûh b. Derrâc bu iki rivayette de teferüd etmiştir.

Nûh b. Derrâc'ın yer aldığı bazı isnadların, başka isnadlara tercih edildiği de olmuştur. Mesela Yahyâ b. el-Cezzâr'ın Muâz b. Cebel'den naklettiğine göre Hz. Peygamber Muâz'1 Yemen'e gönderirken develerin zekatı bağlamında otuz deveden bir yaşını doldurmuş iki yaşına basmış tebî‘ denilen bir dana (Erdoğan, 2005: 553) ve kırk deveden ise üç yaşına basmış ve mesene olarak isimlendirilen bir dananın alınmasını emretti. Söz konusu rivayet Yahyâ b. Ebî Enîse $\rightarrow$ Hakem $\rightarrow$ Yahyâ b. el-Cezzâr $\rightarrow$ Muâz b. Cebel isnadiyla nakledilmiştir. Nûh b. Derrâc ise rivayeti Yahyâ b. Ebî Enîse $\rightarrow$ Hakem $\rightarrow$ Yahyâ b. el-Cezzâr isnadıyla mürsel olarak nakletmiştir. Dârekutnî rivayetle ilgili bu tarikleri verdikten sonra "doğru olan mürsel rivayettir" diyerek Nûh b. Derrâc'1n rivayetini tercih etmiştir. Aynı şeklide Nûh b. Derrâc'1n, Hz. Peygamber'in Ammâr b. Yâsir için "Tayyib ve Tayyib olunan kişiye merhaba" dediği rivayeti de de Süfyân es-Sevrî ve diğerlerine muvafik olarak nakletmiştir (Dârekutnî, 2011: 2, 95). Bu da Nûh b. Derrâc'nn sikalara sürekli muhalefet etmediğini göstermektedir. 
Görüldüğü gibi Nûh b. Derrâc ile ilgili en ağır cerh Yahyâ b. Maîn'den gelmiştir. Yahyâ b. Maîn'in sözlerinden de anlaşıldığına göre Nûh b. Derrâc'ın tenkit edilmesinin sebebi garib rivayetleri nakletmesidir. Ancak bu durumun, cerhin en ağır ifadelerinden olan kezzâb gibi bir sonuca sebep olduğunu söylemek zordur. Bunun yanı sıra İbn Maîn'in çağdaşı olan ve özellikle de Kûfe râvileri konusunda görüşü muteber kabul edilen İbn Numeyr'in Nûh b. Derrâc'1 sika kabul etmesi önemlidir. Bununla beraber Buhâri başta olmak üzere bazı hadis münekkitlerinin, Nûh b. Derrâc'1 daha hafif ifadelerle tenkit etmeleri, üzerinde düşünülmesi gereken önemli bir husustur. Bu bağlamda İbn Maîn ve Hâkim en-Nîsâbûrî başta olmak üzere bazı âlimler tarafindan kezzâb olmakla ve hadis uydurmakla nitelenmesinin tenkide açık yaklaşımlar olduğu söylenebilir. Bunun yerine Buhârî ve Ebû Hâtim gibi âlimlerin görüşlerinin daha kabul edilebilir olduğu düşünülebilir. Bununla beraber Nûh b. Derrâc'in çok az hadis rivayet ettiği, dolayısıyla hadis râvisi olarak da ön plana çıkmadığı görülmektedir.

\section{Kadı Ebû'l-Bahterî Vehb b. Vehb (ö. 200/816)}

Ebû'l-Bahterî künyesiyle bilinen Vehb'in nesebi; Vehb b. Vehb b. Kesîr b. Abdullah b. Zam'a b. el-Esved b. Muttalib b. Esed b. Abdüluzzâ b. Kusay'dır. Aslen Medîne'li olan Ebû'lBahterî daha sonra Şam'a ve Bağdâd'a gitmiştir. Hârûnürreşîd (ö. 193/809) tarafindan önce Bağdat'a, sonra Medîne'ye kadı olarak atanmıștır (İbn Sa'd, 1990: 7, 240). Vekî‘'in (ö. 306/918) nakline göre Vehb, hicri 192 tarihinde Hişâm b. Abdullah b. İkrime'den sonra Medîne'nin kadıs1 olmuştur (Vekî', 1947: 1, 243).

Ebû'l-Bahterî; Hişâm b. Urve (ö. 146/763), Ca'fer b. Muhammed (ö. 148/766), Ubeydullah b. Ömer (ö. 145-147/763-765 aras1) ve başkalarından rivayet etmiştir. Kendisinden de Müseyyeb b. Vâdıh (ö. 247/862), Recâ b. Sehl (ö. 251-260/865-874 arası) ve başkaları nakilde bulunmuştur. Ebû'l-Bahterî yetmiş küsur yaşında 200/816 tarihinde Bağdât'ta vefat etmiştir. Ayrıca Ebû'lBahterî'nin, neseb ve megâzî gibi konularda eserler de telif ettiği söylenmiştir (İbn Asâkir, 1995: 63, 407; Zehebî, 1985: 9, 374).

Ebû'l-Bahterî, Hâkim en-Nîsâbûrî tarafindan hadis uydurmakla suçlanmıştır (Hâkim enNîsâbûrî, 2009: 1, 235). Nesâî, "Hadisçiliği ile bilinen kadılar" adına bir başlık açmış, bu başlı̆̆ın altında Ebû'l-Bahterî'yi de zikretmiştir (Nesâî, 1423: 75). Ebû'l-Bahterî her ne kadar Nesâî tarafından hadisçi kadı olarak nitelenmişse de hadis münekkitleri tarafindan en ağır ifadelerle tenkit edilmiştir. Söz gelimi İbn Sa'd'a (ö. 230/845) göre hadis ilminde Ebû'l-Bahterî’ye itibar edilmezdi. Münker rivayetleri naklettiği için hadisleri terk edilmiştir (İbn Sa'd, 1990: 7, 239-240). Mâlik b. Enes'ten şöyle bir rivayet nakledilmiştir: "Bazı insanlara ne oluyor da Medîne'den çıktığında; ' $\mathrm{Ca}$ ' fer b. Muhammed bize tahdîs etti, Ca'fer b. Muhammed bize tahdîs etti' diyerek rivayette bulunuyorlar. Oysa bu kişiler Medîne'ye döndüğünde evlerine kapanıyorlar” demiştir. Vekî' 'e göre Mâlik bu sözüyle Ebû'l-Bahterî'yi kastetmiştir (Vekî', 1947: 1, 252).

Ebû'l-Bahterî'yi ağır bir şekilde eleştiren âlimlerden birisi Yahya b. Maîn'dir. İbn Maîn onun güvenilir ve sika olmadığını (Yahyâ b. Maîn, 2008: 73), bilakis Allah düşmanı, kezzâb ve habîs olduğunu ifade etmiştir (Yahyâ b. Maîn, 2009: 75). Ayrıca İbn Maîn, Ebû'l-Bahterî’nnin bir daire kiraladığını ve burada gece boyunca hadis uydurduğunu söylemiş, örnek olarak da Hişâm b. Urve $\rightarrow$ babası Urve $\rightarrow \mathrm{Hz}$. Âişe tarikiyle uydurduğu bir rivayete işaret etmiştir (Yahyâ b. Maîn, 1979: 3, 554).

Ahmed b. Hanbel'e hadis uyduranın olup olmadığı sorulması üzerine: "Evet (hadis uyduran vardır)! Kadı olan Ebû'l-Bahterî yalancıdır, hadis uydururdu, hiç kimsenin rivayet etmediğini rivayet ederdi" şeklinde cevap vermiştir (İbn Ebî Hatim, 1952: 9, 25). İshâk b. Râhûye (ö. 238/853) ve Ebû Hâtim de (ö. 277/890) onun kezzâb olduğunu vurgulamışlardır (İbn Ebî Hatim, 1952: 9, 26). Buhârî de (ö. 256/870) Ebû'l-Bahterî ile ilgili şöyle demiştir: "Onun hakkında sükut etmişler, Vekî' onun yalancı olduğunu söylemiştir" (Buhârî, 1362: 8, 170). Müslim de (ö. 261/875) onu "metrûkü'l-hadîs" ifadesiyle nitelemiştir (Müslim, 1984: 1, 153). Aynı şekilde Cûzcânî (ö. 259/873) (Cûzcânî, 1985: 134), Ebû Zür‘a er-Râzî (ö. 264/878) (Ebû Zür'a er-Râzî, 2009: 368), Nesâî (Nesâi, 1396: 104), Vekî‘ 
(Vekî', 1947: 1, 244), İbn Hibbân (İbn Hibbân, 1396: 2, 415), Dârekutnî (Dârekutnî, 1986: 4, 1948) başta olmak üzere birçok hadis münekkidi tarafından cerhin en ağır ifadeleriyle tenkit edilmiştir. Tespit edebildiğimiz kadarıyla hadis münekkitleri içerisinde Ebû'l-Bahterî’yi güvenilir gören hiç kimse bulunmamaktadır.

\subsection{Hadis Literatüründe Ebû'l-Bahterî’nin Rivayetleri}

Hadis münekkitleri, Ebû'l-Bahterî tarafindan uydurulan bir takım rivayetlere işarette bulunmuştur. Söz gelimi İbn Adî’nin “Kim ümmetime fayda sağlayacak kırk hadisi ezberlerse, Allah kıyamet gününde onu fakîh ve âlim olarak diriltecektir" rivayetinin Ebû'l-Bahterî tarafından uydurulduğunu ifade etmiştir. Bunun yanı sıra İbn Adî’nin, Ebû'l-Bahterî’nin uydurduğu rivayetleri sika râvilerden oluşan senedlerle rivayet ettiğini söylemiştir. Ayrıca İbn Adî, Ebû'l-Bahterî'nin uydurduğu rivayetlerin sayısının kendisinin zikrettiğinden daha fazla olduğunu dile getirmiştir (İbn Adî, 2013: 8, 338).

Ebû'l-Bahterî’nin, dönemin idarecilerini memnun etmek adına hadis uydurduğu nakledilmiştir. Söz gelimi kendisi kadı iken bir gün Hârûnürreşîd'in güvercinlerle ilgilendiği bir sırada huzuruna çıkmış, Hârûnürreşîd kendisine güvercinlerle ilgili herhangi bir rivayeti bilip bilmediğini sormuştur. Bunun üzerine Ebû'l-Bahterî "Bana Hişâm b. Urve tahdîs etti, o da babasından, o da Hz. Âişe'nin; "Hz. Peygamber'in güvercinleri uçurduğunu” söylediğini rivayet etmiştir. Hârûnürreşîd bu sözü duyunca onu huzurdan çıkarmış ve "Eğer Kureyş’ten olmasaydı onu kadılıktan azlederdim" demiştir (Hatîb el-Bağdâdî, 2002: 15, 625).

Dârekutnî de Ebû'l-Bahterî'nin, Ubeydullah $\rightarrow$ Nâfi' $\rightarrow$ İbn Ömer tarikiyle hadis uydurduğunu söylemiştir (Dârekutnî, 2011: 13, 36). Aynı şeklide İbnü'l-Cevzî Kitâbü'l-Mevzûât adlı eserinde naklettiği rivayetlere yer vermiş ve onun yalancıların büyüklerinden olduğunu vurgulamıştır (İbnü'l-Cevzî, 1997: 1, 35-206; 2, 358-528).

Gerek hadis münekkitlerinin görüşleri, gerekse de Ebû'l-Bahterî'nin naklettiği rivayetler göz önünde bulundurulduğunda kendisinin uydurma rivayetlerde bulunduğu söylenebilir. Ayrıca onun hadis uydurduğuna dair birçok hadis münekkidi görüş birliği içerisinde olduğu da görülmektedir.

\section{Sonuç}

Kadıları genel anlamda hadis rivayetiyle ilişkilendirmek mümkündür. Ancak bazı istisnalarla beraber fetvayla ve fikıhla meşhur olanların hadis rivayetinde de ön plana çıktığı söylenemez. Bunun yanı sıra hadis âlimlerinin kadılık mesleğine olumlu bakmadıkları görülmektedir. Bunun temel nedeni, kadılık gibi hadis dışı meşguliyetlerin râvilerin zabtlarına olumsuz etki etmesidir. Bundan olsa gerektir ki, bazı râviler kadılık görevini üstlendikten sonra rivayetleri terk edilmiş ve hadisleri delil olarak kabul edilmemiştir.

Hâkim en-Nisâbûrî; Mansûr b. Abdülhamid, İbn 'Ulâse, Nûh b. Derrâc ve Ebû'l-Bahterî isimli kadıları hadis uydurmakla itham etmiştir.

Hadis uydurmakla itham edilen Mansûr b. Abdülhamid'le ilgili Yahyâ b. Maîn, Ahmed b. Hanbel, Buhârî ve Ebû Hâtim gibi hadis münekkitlerinin görüşlerine rastlanılmadı.

İbn Hibbân ve İbn Asâkir gibi âlimler Mansûr b. Abdülhamid'i hadis uydurmakla itham etmişlerdir. Bunun yanı sıra Mansûr b. Abdülhamid'in rivayeti temel hadis kaynaklarında yer almamıştır. Dolayısıyla Mansûr b. Abdülhamid'in hadis râvisi olarak pek de ön plana çıkmadığı söylenebilir. Bu bağlamda ilk dönem münekkitlerinin onun hakkında kanaat belirtmemelerin sebebi de bu olsa gerektir.

Hâkim en-Nîsâbûrî’nin, Mehdî tarafindan kadı olarak atanan İbn 'Ulâse’yi hadis uydurmakla suçlamış, hadis münekkitleri tarafından ise farklı değerlendirmeler yapılmıştır. Söz gelimi İbn Sa'd 
ve Yahyâ b. Maîn onu sika kabul etmişlerdir. Buna mukabil Ebû'l-Feth ve İbn Hibbân İbn 'Ulâse'yi kezzâb olmakla ve hadis uydurmakla itham etmişlerdir.

Hadis literatürü tarandığında İbn 'Ulâse'nin çok rivayeti olmadığı görülmektedir. Tespit edilebildiği kadarıyla İbn 'Ulâse'nin rivayetleri Buhârî ve Müslim Sahîh'lerinde yer almamaktadır. Ondan Ebû Dâvud bir; İbn Mâce', Nesâî ve Ahmed b. Hanbel iki rivayet tahrîc etmiştir. Bunun yanı sıra Abdürrezzâk es-San'ânî iki, İbn Ebî Şeybe dört fetvasını nakletmiştir.

"İbn 'Ulâse naklettiği bazı rivayetlerinde hata yapmıştır" denilebilir. Ancak bu hatalar İbn 'Ulâse'nin zabtının zayıflığı bağlamında değerlendirilmelidir. Hal böyleyken Ebû'l-Feth el-Ezdî, İbn Hibbân ve Hâkim en-Nîsâbûrî gibi bazı âlimlerin onu "İbn 'Ulâse yalancıdır, ondan rivayet etmek helal değildir” şeklinde değerlendirmelerinin çok ağır ve tenkide açık olduğu söylenebilir.

Hâkim en-Nîsâbûrî tarafindan hadis uydurmakla itham edilen kadılardan birisi Nûh b. Derrâc'tır. Yahyâ b. Maîn onu yalancı ve habîs olarak nitelemiştir. Aynı şekilde Ebû Dâvud, Nesâî ve İbn Hibbân Nûh b. Derrâc'ın hadis uydurduğunu söylemişlerdir.

Hadis münekkitlerinden Buhârî, İclî, Ebû Hâtim er-Râzî, Ali b. Medînî ise Nûh b. Derrâc’1 daha hafif ifadelerle tenkit etmişlerdir. Bu münekkitlerin yaptıkları tenkit daha çok onun zabtına yönelik olmuştur. Muhammed b. Abdullah b. Numeyr ise Nûh b. Derrâc'1 sika tabiriyle nitelemiş, Ebû Zür'a da ondan hadis alınmasında herhangi bir beis olmadığını umut etmiştir. Bunun yanı sıra İbn Adî Nûh b. Derrâc'ı hadisi yazılan râvilerden kabul etmiştir. İbn Numeyr'in özellikle de Kûfe râvileri konusundaki yaklaşımı Yahyâ b. Maîn ve Ahmed b. Hanbel tarafindan hüsnü kabul görmüş̧ür. Nûh b. Derrâc da Kûfe'li olduğuna göre İbn Numeyr'in onu sika kabul etmesi önemlidir.

Kütüb-i Sitte müellifleri ve Ahmed b. Hanbel gibi muhaddisler Nûh b. Derrâc'tan hadis tahrîc etmemişlerdir. Bununla beraber Ebû Hanîfe'nin Müsned'inde Nûh b. Derrâc'ın rivayetlerini bulmak mümkündür. Ayrıca Nûh b. Derrâc'ın bazı rivayetlerinde sika râvilere muhalefet ettiği tespit edilmiştir. Bu bağlamda İbn Maîn ve Hâkim en-Nîsâbûrî başta olmak üzere bazı âlimler tarafindan kezzâb olmakla ve hadis uydurmakla nitelenmesinin tenkide açık yaklaşımlar olduğu düşünülebilir. Bunun yerine Buhârî ve Ebû Hâtim gibi âlimlerin görüşlerinin daha makul olduğu kabul edilebilir. Bununla beraber Nûh b. Derrâc'ın çok az sayıda hadis rivayet ettiği, dolayısıyla hadis râvisi olarak ön plana çıkmadığı da bir hakikattir.

Hâkim en-Nîsâbûrî başta olmak üzere hadis münekkitleri tarafindan hadis uydurmakla tavsîf edilen kadılardan birisi olan Ebû'l-Bahterî, Hârûnürreşîd tarafindan önce Bağdat'a daha sonra Medîne'ye kadı olarak atanmıştır.

Ebû'l-Bahterî; Yahyâ b. Maîn, Ahmed b. Hanbel, İshâk b. Râhûye, Buhârî Müslim ve Ebû Hâtim gibi hadis münekkitleri tarafından kezâb olmakla ve hadis uydurmakla nitelenmiştir. Aynı şekilde Cûzcânî, Ebû Zür'a er-Râzî, Nesâî, Vekî‘, İbn Hibbân ve Dârekutnî de onu cerhin en ağır ifadeleriyle tenkit etmişlerdir. İbn Adî, Dârekutnî ve İbnü'l-Cevzî Ebû'l-Bahterî tarafindan uydurulan birtakım rivayetlerine işarette bulunmuşlardır. Hal böyleyken "Ebû'l-Bahterî hadis uydurmuştur" görüşünün ön plana çıtığı görülmektedir. Yukarıda yapılan açıklamalar bağlamında Hâkim en-Nîsâbûrî’nin, Mansûr b. Abdülhamid ve Ebû'l-Bahterî ile ilgili görüşü muteber olarak değerlendirilebilir. Ancak İbn 'Ulâse ve Nûh b. Derrâc ile ilgili ortaya koyduğu yaklaşımın tenkide açık olduğu anlaşılmaktadır.

\section{Kaynakça}

Ahmed b. Hanbel, E. A. A. b M. eş-Şeybani. (2001). el-Müsned (C. 1-45). Müessesetü’r-Risâle.

Aydınlı, A. (2009). Hadis ıstılahları sözlü̆̆̈̈ (3. Baskı). İFAV Yayınları.

Beyhakî, E. B. A. b el-H. b A. (1344). es-Sünenü'l-kübra. Dâiretü'l-Maârifi'l-Osmaniyye. 
Beyhakî, E. B. A. b el-H. b A. (2003). Şuabü'l-îmân (C. 1-14). Mektebetü'r-Rüşd.

Buhârî, Ebû Abdillâh Muhammed b İsmâîl b İbrâhîm Cu'fî. (1422h). Sahîh. Dâru Tavki'n-Necât.

Buhârî, Ebû Abdillâh Muhammed b İsmâîl b İbrâhîm Cu'fî. (1362). et-Târihü'l-kebîr (C. 1-8). Dâiretü'l-Maârifi'l-Osmâniyye.

Buhârî, Ebû Abdillâh Muhammed b İsmâîl b İbrâhîm Cu'fî. (2005). ed-Duafâü's-sagîr. Mektebetü İbn Abbâs.

Cûzcânî, E. İ. İ. b Y. b İ. es-Sa'dî. (1985). Ahvâlü'r-ricâl. Müessesetü'r-Risâle.

Dârekutnî, E.-H. A. b Ö. b A. (1986). el-Mu'telif ve'l-muhtelif (C. 1-5). Dârü'l-Garbi'l-İslâmî.

Dârekutnî, E.-H. A. b Ö. b A. (2004). Sünenü'd-Dârekutnî (C. 1-5). Müessesetü'r-Risâle.

Dârekutnî, E.-H. A. b Ö. b A. (2011). el-İlelü'l-varide fi'l-ehâdîsi'n-nebeviyye (C. 1-10). Müessesetü'r-Rayyân.

Düzenli, M. (2013). Bir Tenkit Terimi Olarak “Sülûkü’l-câdde”. İslam Araştırmaları Dergisi, 30, 123.

Ebû Dâvud, S. b E. b İ. b el-Ezdi es-Sicistânî. (1998). Sünen. Darü'l-Kıble li's-Sekafeti'l-İslamiyye.

Ebû Nuaym, A. b A. b İ. el-İsfahânî. (1984). Kitâbü'd-du'afâ. Dârülbeyzâ: Dârü's-Sekâfe.

Ebû Nuaym, A. b A. b İ. el-İsfahânî. (1988). Ma'rifetü's-sahâbe (C. 1-7). Dârü'l-Vatan.

Ebû Zür'a er-Râzî, U. b A. b Y. (2009). Su'âlâtü'l-Berze'î li Ebî Zür'a er-Râzî. el-Fârukü'l-Hadîse. el-Fesevî, E. Y. Y. b S. (1981). el-Ma'rife ve't-târîh (C. 1-3). Müessesetü'r-Risâle.

el-Hârisî, E. M. A. b. M. b. Y. b. H. b. H. H. B. (2010). Müsnedü'l-Imam el-A'zam Ebî Hanîfe enNu'mân b. Sâbit el-Kûfí (C. 1-2). el-Mektebetü'l-İmdadiyye.

el-Kemlâî, M. H. b M. (2018). el-Büdûrü'l-madiyye fi terâcimi'l-Hanefiyye (2. Bask1, C. 1-23). Dârü's-Sâlih.

Erdoğan, M. (2005). Fikıh ve hukuk terimleri sözlügü̈. Ensar Neşriyat.

es-San'ânî, E. B. A. b H. A. (2010). el-Musannef. Dâru't-Te'sîl.

es-Siczî en-Nîsâbûrî, E. A. İ.-B. M. H. (2006). Su'âlât Mes'ûd b. Ali es-Siczî li Ebî Abdullah elHâkim en-Nîsâbûrî. el-Fârûku'l-Hadîse.

Hâkim en-Nîsâbûrî, E. A. İ.-B. M. (1990). el-Müstedrek ale's-Sahîhayn (C. 1-4). Dârü'1-Kütübi'lİlmiyye.

Hâkim en-Nîsâbûrî, E. A. İ.-B. M. (2009). el-Medhal ila ma 'rifeti's-sahîh mine's-sakîm ve tebyîn mâ eşkele min esmâi' 'r-ricâl fì's-sahîhayn (C. 1-4). Müessesetü'r-Risâle.

Hatîb el-Bağdâdî, E. B. A. b A. b S. (2002). Târîhu Bağdâd (C. 1-16). Dârü'1-Garbi'l-İslamî.

İbn Adî, E. A. A. b A. el-C. İ. (2013). el-Kamil fî duafai'r-rical (C. 1-11). Mektebetü’r-Rüşd.

İbn Asâkir, E.-K. S. A. b H. b H. (1995). Târîhu medîneti Dımaşk. (C. 1-80). Dârü’l-Fikr.

İbn Asâkir, E.-K. S. A. b H. b H. (2000). Mu'cemü'ş-şüyûh (C. 1-3). Dârü'l-Beşâir.

İbn Ebî Hatim, E. M. A. b. M. b. İ. R. (1952). el-Cerh ve't-ta 'dîl (C. 1-9). Dâru İhyâi't-Turâsi'lArabî.

İbn Ebî Şeybe, E. B. A. b M. b İ. (2009). el-Musannef fi'l-ehâdîs ve'l-âsâr (C. 1-13). Dârü'l-Fârûk. İbn Hacer, E.-F. Ş. A. el-Askalânî. (2002). Lisânü'l-mîzân. Dâru'l-Beşâri'l-İslâmiyye. 
İbn Hacer, E.-F. Ş. A. el-Askalânî. (1326). Tehzîbü't-Tehzîb. Dâiretü'l-Maârif.

İbn Hibbân, E. H. M. b H. b A. B. (1396). Kitâbü'l-mecrûhîn (C. 1-3). Dârü'l-Va'y.

İbn Mâce, E. A. M. b Y. er-Rebei el-Kazvini. (2009). Sünen. Dâru'r-Risâleti’l-Âlemiyye.

İbn Receb, E.-F. Z. A. b A. (1988). et-Tahvîf mine'n-nâr ve't-ta'rîf bi-hâli dâri'l-bevâr. Dârü'lBeyân.

İbn Sa'd, E. A. M. (1990). et-Tabakâtü'l-kübrâ (C. 1-8). Dârü'l-Kütübi'l-İlmiyye.

İbnü'l-Cevzî, E.-F. C. A. b A. b M. B. (1986). ed-Duafâ ve'l-metrukîn. (C. 1-5). Dârü'l-Kütübi'1İlmiyye.

İbnü'l-Cevzî, E.-F. C. A. b A. b M. B. (1997). Kitâbü'l-mevzûât mine'l-ehâdîsi'l-merfûât (C. 1-3). Mektebetu Edvai's-Sele.

İclî, E.-H. A. b A. b S. (1985). Ma'rifetü's-sikât (C. 1-2). Mektebetü'd-Dâr.

Juynboll, G. H. A. (2002). Hadis tarihinin yeniden inşâsı (S. Özer, Çev.). Ankara Okulu.

Kandemir, M. Y. (1997). "Hâkim en-Nîsâbûrî", Türkiye Diyanet Vakfi İslâm Ansiklopedisi (C. 15, ss. 190-193). TDV Yayınları.

Karagözoğlu, M. M. (2014). Zayıf râviler: Duafa literatürü ve zayıf rivayetler. M.Ü. İlahiyat Fakültesi Vakfi.

Koç, E. (2019). Hicrî ilk iki asır Kûfe kadılarının hadisle ilişkisi [Yayımlanmamış Yüksek Lisans Tezi]. Üniversitesi Sosyal Bilimler Enstitüsü.

Koçinkăg, M. (2017). Hicrî İlk İki Asırda Irak’ta Görev Yapan Kadılar. Çanakkale Onsekiz Mart Üniversitesi Illahiyat Fakültesi Dergisi, 11, 27-44.

Mizzî, E.-H. C. Y. b A. b Y. (1980). Tehzîbü'l-Kemâl fì esmâi'rr-ricâl (C. 1-35). Müessesetü'r-Risâle.

Müslim b. Haccâc, E.-H. el-Kuşeyrî en-Nisâbûrî. (1984). el-Künâ ve'l-esmâ (C. 1-2). İmâdetü'1Bahsi'l-İlmî.

Nesâî, E. A. A. b. A. b. Ş. (1396). ed-Duafa ve'l-metrûkîn. Haleb: Dârü'l-Va'y.

Nesâî, E. A. A. b. A. b. Ş. (1423). Tesmiyetü meşâyihi Ebî Abdirrahman Ahmed b. Şuayb b. Ali enNesâ̂ ve zikrü'l-müdellisîn. Âlemü'l-Fevâid.

Nesâî, E. A. A. b A. b Ş. (1986). Sünen. Mektebetü'l-Metbûâti'l-İ́slâmiyye.

Öztoprak, M. (2013). Endülüs Hadisçiliğinde Kadıların Yeri. Şırnak Üniversitesi Illahiyat Fakültesi Dergisi, 4/7, 102-122.

Sa'lebî, E. İ. A. b M. b İ. en-Nîsâbûrî. (2002). el-Keşf ve'l-beyân an tefsîri'l-Kur'ân (C. 10). Dâru İhyai't-Türasi'l-Arabi.

Taberânî, E.-K. M.-D. S. b A. b E. (t.y.). el-Mu'cemü'l-evsat (C. 1-10). Dârü'l-Haremeyn.

Taberânî, E.-K. M.-D. S. b A. b E. (1984). Müsnedü'ş-şâmiyyîn (C. 1-4). Müessesetü’r-Risâle.

Topgül, M. E. (2019). Rivayetten raviye: Cerh-ta'dil hükümleri nasıl Oluştu?. M.Ü. İlahiyat Fakültesi Vakfı Yayınları.

Ukaylî, E. C. M. b A. b M. b H. (2008). ed-Duafäü'l-kebîr (C. 1-6). Mektebetü İbn Abbâs.

Ünal, İ. H. (2010). İmam Ebu Hanîfe'nin hadis anlayışı ve hanefi mezhebinin hadis metodu (3. Bask1). Diyanet İşleri Başkanlığı.

Vekî’, E. B. M. b H. b H. ed-Dabbi. (1947). Ahbârü'l-kudât (C. 1-3). Âlemü'l-Kütüb. 
Yahyâ b. Maîn, Ebû Zekeriyyâ el-Bağdâdî. (1979). Târîhu İbn Maîn (Rivâyetü'd-Dûrî) (C. 1-4). Merkezü'l-Bahsi'l-İlmi ve İhyâi't-Türâsi'l-İslâmî.

Yahyâ b. Maîn, Ebû Zekeriyyâ el-Bağdâdî. (2008). Min kelami Ebî Zekeriyya Yahya b. Ma'în: Rivayetü Ebî Hâlid Yezîd b. El-Heysem b. Tahmân el-Bâdî ed-Dekkâk. Dârü'l-Fârûkü'lHadîse.

Yahyâ b. Maîn, Ebû Zekeriyya el-Bağdâdî. (2009). Ma'rifetü'r-ricâl (Rivâyetu İbn Muhriz). elFârûku'l-Hadîse.

Zehebî, E. A. Ş. M. b A. b O. (1963). Mîzânü̉'l-i'tidâl fí nakdi'r-ricâl (C. 1-4). Dârü'l-Ma'rife.

Zehebî, E. A. Ş. M. b A. b O. (1985). Siyeru a 'lâmi 'n-nübelâ (C. 1-25). Müessesetü'r-Risâle.

Zehebî, E. A. Ş. M. b A. b O. (2003). Târîhü'l-İslâm ve vefeyâtü'l-meşâhîr ve'l-a'lâm (C. 1-15). Dârü'l-Garbi'l-İslâmî. 